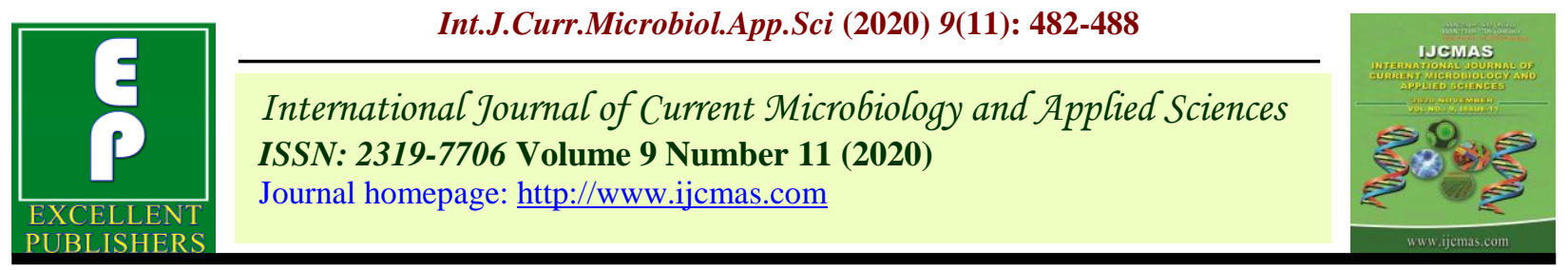

Original Research Article

https://doi.org/10.20546/ijcmas.2020.911.059

\title{
Effect of Integrated Nutrient Management on Flowering, Fruit Yield and Quality of Aonla (Emblica officinalis Gaertn) cv. Chakaiya
}

\author{
Balram Pusam* and Deepansu Masih \\ Department of Horticulture, Sam Higginbottom University of Agriculture Technology and \\ Science, Prayagraj, India \\ *Corresponding author
}

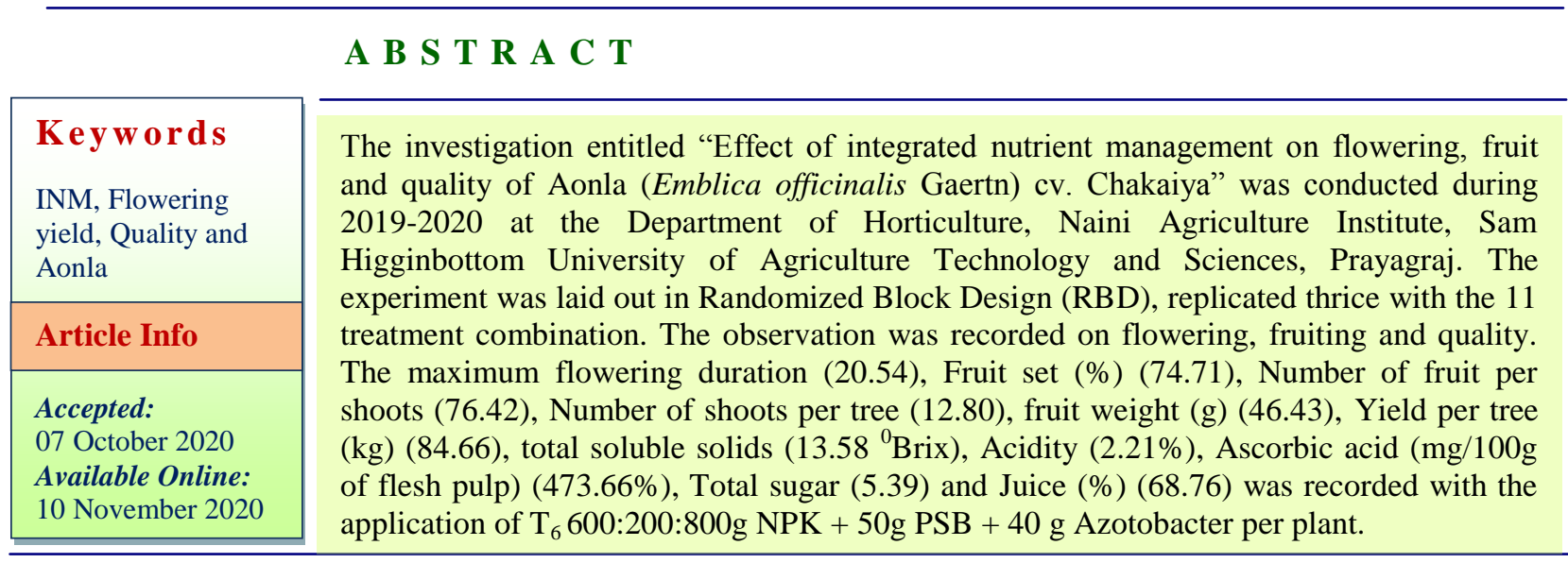

\section{Introduction}

Aonla or Indian gooseberry (Emblica officinalis Gaertn.) is indigenous to Indian sub-continent, belongs to the family Euphorbiaceae. It is the richest source of vitamin $\mathrm{C}(400-1300 \mathrm{mg} / 100 \mathrm{~g}$ from pulp) among the fruits next to Barbados cherry (Mandal et al., 2013). Owing to its hardy nature, suitability to various wastelands, high productivity, nutritive and therapeutic values, aonla has become an important fruit. Alternate land use systems, particularly agrihorti systems with the inclusion of aonla (Emblica officinalis Gaertn.) on marginal, less productive soils, has a tremendous potential in
Bundelkhand region (Pathak and Bhatt, 2001). The edible fruit is highly nutritious and is the richest source of vitamin -C (400$1300 \mathrm{mg} 100-1 \mathrm{~g}$ fruit pulp) among the fruits next to Barbados cherry (Asenjo, 1953). Soil type, fertility and nutrient management play important roles in obtaining higher growth and yields of aonla. Its fruit is a tonic for diuretic, laxative, antioxidant and act as cooling refrigerant. It is the richest source of vitamin "C" (600mg /100g) among all fruit, except Barbados cherry and fruit contain 8994\% pulp, 0.8, $2.0 \%$ Fibre, $10-14 \%$ TSS, $1.4-$ 2.4 , acidity $2.4-3.1 \%$ protein and 2.0-3.05 Phenols (Singh et al., 1993). In India aonla is widely distribution in the Himalaya region, 
Chhota Nagpur, Bihar, Orissa, West Bengal Decan and Karnataka. The total cultivated area under aonal in India is 93, 000 ha with and annual production of 10,77,000 MT (NHB, 2017-2018). The forest of M. P. has a rich diversity of aonla, Major aonla producing areas in Madhya Pradesh are Sheopur, Betul, Balaghat, Satna, Sidhi, Ratlam, Mandsaur and Neemuch district.

\section{Materials and Methods}

The investigation entitled "Effect of integrated nutrient management on flowering, fruit and quality of Aonla (Emblica officinalis Gaertn) cv. Chakaiya" was conducted during 2019-2020 at the Department of Horticulture, Naini Agriculture Institute, Sam Higginbottom University of Agriculture Technology and Sciences, Prayagraj. The experiment was laid out in Randomized Block Design (RBD), replicated thrice with the 11 treatment with combination of $\mathrm{T}_{0}$ control, $\mathrm{T}_{1}: 800: 400: 800 \mathrm{~g}$ NPK per plant, $\mathrm{T}_{2}$ : 400:200:400g NPK +10kg FYM per plant, $\mathrm{T}_{3}$ : 400:200:400g NPK + $10 \mathrm{~kg}$ Vermicompost per plant, $\mathrm{T}_{4}: 800: 200: 400 \mathrm{~g} \mathrm{NPK}+50 \mathrm{~g}$ PSB per plant, $\mathrm{T}_{5}: 600: 400: 800 \mathrm{~g} \mathrm{NPK}+400 \mathrm{~g}$ Azotobacter per plant, $\mathrm{T}_{6}: \quad 600: 200: 800 \mathrm{~g}$ $\mathrm{NPK}+50 \mathrm{~g}$ PSB $+40 \mathrm{~g}$ Azotobacter per plant, $\mathrm{T}_{7}:: 400: 0: 400 \mathrm{~g} \mathrm{NPK}+10 \mathrm{~kg} \mathrm{FYM}+50 \mathrm{~g}$ PSB per plant, $\mathrm{T}_{8}: \quad 400: 0: 400 \mathrm{~g}$ NPK $+10 \mathrm{~kg}$ Vermicompost $+50 \mathrm{~g}$ PSB per plant and $\mathrm{T}_{9}$ : 200:0:400g NPK + $10 \mathrm{~kg}$ FYM+50g PSB+40g Azotobacter per plant and $\mathrm{T}_{10}$ :200:0:400g NPK + $10 \mathrm{~kg}$ Vermicompost + $50 \mathrm{~g}$ PSB $+40 \mathrm{~g}$ Azotobacter per plant.

The observation were recorded on flowering, fruiting and quality viz., duration of flower, fruit set $(\%)$, number of fruit per shoots, number of shoots per tree, fruit weight $(\mathrm{g})$, yield per tree $(\mathrm{kg})$, total soluble solids ( $\left.{ }^{0} \mathrm{brix}\right)$, acidity (\%), ascorbic acid (mg/100g of flesh pulp), total sugar and juice (\%).The data recorded during the course of investigation were subjected to statistical analysis as per method of analysis of variance (Fisher, 1936).

\section{Results and Discussion}

The data on flowering, fruiting and quality influenced by different treatments are presented in table 1 and graphically delineated in figure 1 . It is vivid from the table that there was significant effect of integrated nutrient management various treatments on duration of flowers. However, the minimum duration (20.54) of flowers was recorded in $\mathrm{T}_{6} 600: 200: 800 \mathrm{~g} \mathrm{NPK}+50 \mathrm{~g} \mathrm{PSB}+$ $40 \mathrm{~g}$ Azotobacter per plant followed by $\mathrm{T}_{8}$ 200:0:400g NPK + $10 \mathrm{~kg}$ FYM+50g PSB $+40 \mathrm{~g}$ Azotobacter per plant, $\mathrm{T}_{3}$ 800:200:400g NPK + 50g PSB per plant and $\mathrm{T}_{1}$ 400:200:400g NPK + 10kg FYM per plant. The minimum duration (30.01) of flowers was recorded in $\mathrm{T}_{0}$ similiar findings were reported by mahantesh kamatyanatti et al., (2019) in plum cv. Kala the maximum Fruit set (\%) (74.71) was recorded in $\mathrm{T}_{6}$ 600:200:800g $\mathrm{NPK}+50 \mathrm{~g}$ PSB $+40 \mathrm{~g}$ Azotobacter per plant followed by $\mathrm{T}_{8}$ 200:0:400g NPK $+10 \mathrm{~kg}$ $\mathrm{FYM}+50 \mathrm{~g}$ PSB + 40g Azotobacter per plant, $\mathrm{T}_{7}$ 400:0:400g NPK + 10kg Vermicompost + 50g PSB per plant and $\mathrm{T}_{9}$ 200:0:400g NPK + $10 \quad \mathrm{~kg} \quad$ Vermicompost $+50 \mathrm{~g} \quad \mathrm{PSB}+40 \mathrm{~g}$ Azotobacter per plant. The minimum fruit set (52.25) of flower per cluster was recorded in $\mathrm{T}_{0}$ Control similiar findings were reported by (Mandal et al., 2013) in Aonla and (Mitra et al., 2010) in Aonla.

The maximum Number of fruit per shoots (76.42) was recorded in $\mathrm{T}_{6}$ 600:200:800g $\mathrm{NPK}+50 \mathrm{~g}$ PSB $+40 \mathrm{~g}$ Azotobacter per plant followed by $\mathrm{T}_{7}$ 400:0:400g NPK $+10 \mathrm{~kg}$ Vermicompost $+50 \mathrm{~g}$ PSB per plant, $\mathrm{T}_{8} 200: 0: 400 \mathrm{~g} \mathrm{NPK}+10 \mathrm{~kg} \mathrm{FYM}+50 \mathrm{~g}$ $\mathrm{PSB}+40 \mathrm{~g}$ Azotobacter per plant, $\mathrm{T}_{3} 800: 200: 400 \mathrm{~g}$ NPK $+50 \mathrm{~g}$ PSB per plant and $\mathrm{T}_{9} \quad$ 200:0:400g NPK $+10 \mathrm{~kg}$ Vermicompost $+50 \mathrm{~g}$ PSB $+40 \mathrm{~g}$ Azotobacter 
per plant The minimum Number of fruit per shoots (28.42) was recorded in $\mathrm{T}_{0}$ Control. similiar findings were reported by Ranjeet Jamra et al., (2020) in Aonla mahantesh kamatyanatti et al., (2019) in plum cv. Kala the maximum Number of shoots per tree (12.80) was recorded in $\mathrm{T}_{6}$ 600:200:800g $\mathrm{NPK}+50 \mathrm{~g}$ PSB $+40 \mathrm{~g}$ Azotobacter per plant followed by $\mathrm{T}_{7}$ 400:0:400g NPK +10kg Vermicompost $+50 \mathrm{~g}$ PSB per plant, $\mathrm{T}_{8} 200: 0: 400 \mathrm{~g}$ NPK $+10 \mathrm{~kg}$ FYM+50g PSB+40g Azotobacter per plant, $\mathrm{T}_{3} 800: 200: 400 \mathrm{~g}$ NPK $+50 \mathrm{~g}$ PSB per plant and $\mathrm{T}_{9}$ 200:0:400g NPK $+10 \mathrm{~kg}$ Vermicompost $+50 \mathrm{~g}$ PSB $+40 \mathrm{~g}$ Azotobacter per plant.

The minimum Number of fruit per shoots (7.26) was recorded in $T_{0}$ Control. similiar findings were reported by Ranjeet Jamra et all.,(2020) in Aonla the maximum fruit weight (g) (46.43) was recorded in $\mathrm{T}_{6}$ 600:200:800g NPK+50g PSB + 40 g Azotobacter per plant followed by $_{1} 400: 200: 400 \mathrm{~g}$ NPK $+10 \mathrm{~kg}$ FYM per plant, $\quad \mathrm{T}_{2} 400: 200: 400 \mathrm{~g} \mathrm{NPK}+10 \mathrm{~kg}$ Vermicompost per plant, $\mathrm{T}_{9}$ 200:0:400g NPK $+10 \mathrm{~kg}$ Vermicompost+50g PSB+40g Azotobacter per plant, $\mathrm{T}_{8} 200: 0: 400 \mathrm{~g}$ NPK + $10 \mathrm{~kg} \mathrm{FYM+50g} \mathrm{PSB+40g} \mathrm{Azotobacter} \mathrm{per}$ plant and $\mathrm{T}_{3} 800: 200: 400 \mathrm{~g}$ NPK+50g PSB per plant.

The minimum fruit weight (g) (17.57) was recorded in $\mathrm{T}_{0}$ Control similiar findings were reported by Darpeet kaur et all.,(2019) in Aonla, Chandra et al.,(2015) in Aonla \& Dinesh et al.,(2014) in Aonla. Ranjeet Jamra et all.,(2020) in Aonla the maximum Yield per tree $(\mathrm{kg})(84.66)$ was recorded in $\mathrm{T}_{6}$ 600:200:800g NPK+50g PSB + $40 \mathrm{~g}$ Azotobacter per plant followed by $\mathrm{T}_{8}$ 200:0:400g NPK + $10 \mathrm{~kg} \mathrm{FYM+50g} \mathrm{PSB} \mathrm{+}$ $40 \mathrm{~g}$ Azotobacter per plant, $\mathrm{T}_{9}$ 200:0:400g $\mathrm{NPK}+10 \mathrm{~kg}$ Vermicompost+50g PSB+40g Azotobacter per plant, $\mathrm{T}_{2}$ 400:200:400g NPK
$+10 \mathrm{~kg}$ Vermicompost per plant and $\mathrm{T}_{3}$ 800:200:400g NPK+50g PSB per plant. The minimum Yield per tree $(\mathrm{kg})$ (38.63) was recorded in $\mathrm{T}_{0}$ Control similar findings were reported by (Mandal et al., 2013) in aonla. Govind vishwakarma et al., (2017) in bael., Darpreet Kaur et al., (2019) in Aonla. Ranjeet Jamra et al., (2020) in Aonla

The maximum total soluble solids (13.58 ${ }^{0}$ Brix) was recorded with $\mathrm{T}_{6}$ 600:200:800g NPK+50g PSB + $40 \mathrm{~g}$ Azotobacter per plant followed by $\mathrm{T}_{7} 400: 0: 400 \mathrm{~g}$ NPK $+10 \mathrm{~kg}$ Vermicompost $+50 \mathrm{~g}$ PSB per plant, $\mathrm{T}_{8}$ 200:0:400g NPK + $10 \mathrm{~kg}$ FYM+50g PSB+40g Azotobacter per plant, $\mathrm{T}_{2}$ 400:200:400g NPK + $10 \mathrm{~kg}$ Vermicompost per plant, $\mathrm{T}_{4} 600: 400: 800 \mathrm{~g} \mathrm{NPK}+400 \mathrm{~g}$ Azotobacter per plant and $\mathrm{T}_{5} 600: 200: 800 \mathrm{~g}$ $\mathrm{NPK}+50 \mathrm{~g}$ PSB $+40 \mathrm{~g}$ Azotobacter per plant and minimum total soluble solid (10.17) was found in $\mathrm{T}_{0}$ Control.

The maximum total soluble solids ( ${ }^{0} \mathrm{Brix}$ ) in $\mathrm{T}_{6}$ may be due to the fact that there was more supplement of nutrients to the plants similiar findings were reported by Ram et al., (2007) in Aonla \& Singh et al., (2018) in Aonla \& Darpreet kaur et al., (2019) in Aonla.

The maximum Acidity (2.21\%) was recorded with $\mathrm{T}_{6}$ 600:200:800g NPK+50g PSB + $40 \mathrm{~g}$ Azotobacter per plant followed by $\mathrm{T}_{5} 600: 200: 800 \mathrm{~g}$ NPK+50g PSB + $40 \mathrm{~g}$ Azotobacter per plant, $\mathrm{T}_{7} 400: 0: 400 \mathrm{~g}$ NPK $+10 \mathrm{~kg}$ Vermicompost $+50 \mathrm{~g}$ PSB per plant, $\mathrm{T}_{8} 200: 0: 400 \mathrm{~g}$ NPK $+10 \mathrm{~kg}$ FYM+50g PSB+40g Azotobacter per plant and $\mathrm{T}_{1} 400: 200: 400 \mathrm{~g}$ NPK + 10kg FYM per plant and minimum Acidity (\%) (1.66) was found in $\mathrm{T}_{0}$ Control (Fig. 2 and Table 2).

The maximum Acidity ( $\%$ ) in $\mathrm{T}_{6}$ may be due to the fact that there was more supplement of nutrients to the plants similar findings were reported by Barath et al., (2019) in Aonla. 
Table.1 Effect of integrated nutrient management on flowering, fruiting and yield of Aonla (Emblica officinalis Gaertn) cv. Chakaiya

\begin{tabular}{|c|c|c|c|c|c|c|}
\hline Treatments No. & $\begin{array}{c}\text { Duration of } \\
\text { flower }\end{array}$ & $\begin{array}{c}\text { Fruit set } \\
\mathbf{( \% )}\end{array}$ & $\begin{array}{c}\text { Number of } \\
\text { fruit per } \\
\text { shoots }\end{array}$ & $\begin{array}{c}\text { Number of } \\
\text { shoots per } \\
\text { tree }\end{array}$ & $\begin{array}{c}\text { Fruit } \\
\text { weight }(\mathbf{g})\end{array}$ & $\begin{array}{c}\text { Yield } \\
\text { per tree } \\
\text { (kg) }\end{array}$ \\
\hline $\mathbf{T}_{\mathbf{0}}$ & 30.01 & 52.25 & 28.42 & 7.26 & 17.57 & 38.63 \\
\hline $\mathbf{T}_{\mathbf{1}}$ & 23.9 & 63.35 & 32.58 & 8.94 & 41.54 & 55.55 \\
\hline $\mathbf{T}_{\mathbf{2}}$ & 25.65 & 58.46 & 48.57 & 10.43 & 38.52 & 72.59 \\
\hline $\mathbf{T}_{\mathbf{3}}$ & 22.27 & 54.56 & 60.79 & 11.25 & 32.5 & 71.6 \\
\hline $\mathbf{T}_{\mathbf{4}}$ & 26.37 & 56.27 & 52.47 & 8.78 & 29.49 & 68.52 \\
\hline $\mathbf{T}_{\mathbf{5}}$ & 26.47 & 55.42 & 54.54 & 8.67 & 24.62 & 65.77 \\
\hline $\mathbf{T}_{\mathbf{6}}$ & 20.54 & 74.71 & 76.42 & 12.8 & 46.43 & 84.66 \\
\hline $\mathbf{T}_{\mathbf{7}}$ & 26.25 & 71.49 & 65.78 & 10.39 & 21.49 & 81.64 \\
\hline $\mathbf{T}_{\mathbf{8}}$ & 21.53 & 72.23 & 62.79 & 10.23 & 30.38 & 82.57 \\
\hline $\mathbf{T}_{\mathbf{9}}$ & 28.5 & 68.41 & 59.78 & 11.44 & 32.84 & 81.41 \\
\hline $\mathbf{T}_{\mathbf{1 0}}$ & 27.21 & 67.98 & 55.26 & 9.68 & 35.57 & 80.14 \\
\hline F-Test & $\mathbf{S}$ & $\mathbf{S}$ & $\mathbf{S}$ & $\mathbf{S}$ & $\mathbf{S}$ & $\mathbf{S}$ \\
\hline C. D. at 0.5\% & $\mathbf{0 . 9 4 2}$ & $\mathbf{1 . 5 5 1}$ & $\mathbf{1 . 5 6 4}$ & $\mathbf{1 . 1 2 4}$ & $\mathbf{1 . 5 5 8}$ & $\mathbf{0 . 7 6}$ \\
\hline S.Ed. & $\mathbf{0 . 4 5 2}$ & $\mathbf{0 . 7 4 4}$ & $\mathbf{0 . 7 5}$ & $\mathbf{0 . 5 3 9}$ & $\mathbf{0 . 7 4 7}$ & $\mathbf{0 . 3 6 4}$ \\
\hline
\end{tabular}

Table.2 Effect of integrated nutrient management on quality of Aonla (Emblica officinalis Gaertn) cv. Chakaiya

\begin{tabular}{|c|c|c|c|c|c|}
\hline Treatments No. & $\begin{array}{c}\text { Total soluble } \\
\left.\text { solids } \mathbf{(}^{\mathbf{0}} \mathbf{B r i x}\right)\end{array}$ & Acidity (\%) & $\begin{array}{c}\text { Ascorbic acid } \\
\text { (mg/100g of } \\
\text { flesh pulp) }\end{array}$ & $\begin{array}{c}\text { Total } \\
\text { sugar }\end{array}$ & Juice (\%) \\
\hline $\mathbf{T}_{\mathbf{0}}$ & 10.17 & 1.66 & 436.72 & 4.29 & 42.78 \\
\hline $\mathbf{T}_{\mathbf{1}}$ & 11.58 & 1.97 & 442.31 & 4.44 & 44.7 \\
\hline $\mathbf{T}_{\mathbf{2}}$ & 12.59 & 1.87 & 438.33 & 4.54 & 45.78 \\
\hline $\mathbf{T}_{\mathbf{3}}$ & 11.65 & 1.84 & 441.54 & 4.56 & 48.63 \\
\hline $\mathbf{T}_{\mathbf{4}}$ & 12.51 & 1.91 & 448.55 & 4.79 & 53.52 \\
\hline $\mathbf{T}_{\mathbf{5}}$ & 12.16 & 2.02 & 442.46 & 4.75 & 67.76 \\
\hline $\mathbf{T}_{\mathbf{6}}$ & 13.58 & 2.21 & 473.66 & 5.39 & 68.76 \\
\hline $\mathbf{T}_{\mathbf{7}}$ & 13.33 & 1.95 & 471.67 & 4.88 & 50.55 \\
\hline $\mathbf{T}_{\mathbf{8}}$ & 13.43 & 1.93 & 469.21 & 4.54 & 53.8 \\
\hline $\mathbf{T}_{\mathbf{9}}$ & 10.57 & 1.73 & 470.93 & 4.49 & 62.39 \\
\hline $\mathbf{T}_{\mathbf{1 0}}$ & 10.68 & 1.74 & 463.87 & 4.54 & 61.5 \\
\hline F-Test & $\mathbf{S}$ & $\mathbf{S}$ & $\mathbf{S}$ & $\mathbf{S}$ & $\mathbf{S}$ \\
\hline C. D. at 0.5\% & $\mathbf{0 . 3 6 4}$ & $\mathbf{0 . 2 4 6}$ & $\mathbf{3 . 1 7}$ & $\mathbf{0 . 1 7 2}$ & $\mathbf{0 . 5 0 4}$ \\
\hline S.Ed. & $\mathbf{0 . 1 7 5}$ & $\mathbf{0 . 1 1 8}$ & $\mathbf{1 . 5 1 9}$ & $\mathbf{0 . 0 8 3}$ & $\mathbf{0 . 2 4 2}$ \\
\hline
\end{tabular}


Fig.1 Effect of integrated nutrient management on flowering, fruiting and yield of Aonla (Emblica officinalis Gaertn) cv. Chakaiya

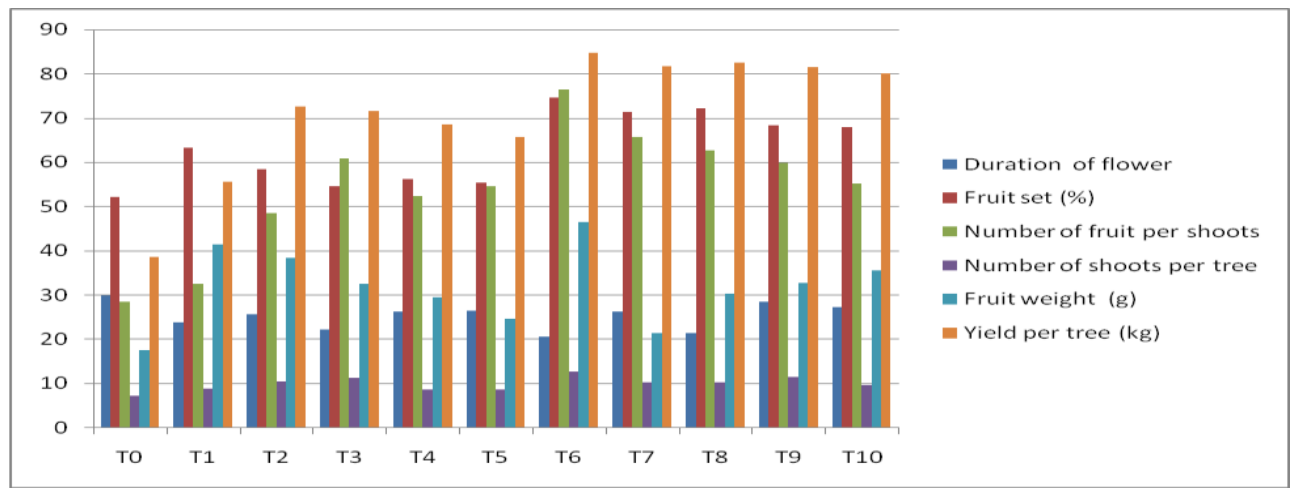

Fig.2 Effect of integrated nutrient management on quality of Aonla (Emblica officinalis Gaertn) cv. Chakaiya

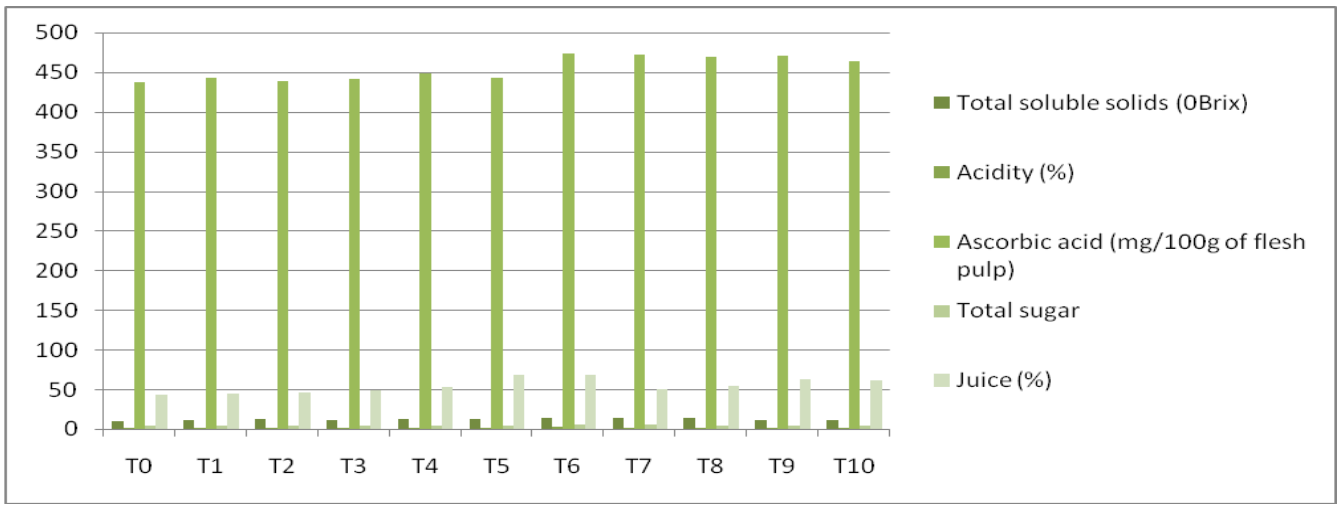

The maximum Ascorbic acid (mg/100g of flesh pulp) $(473.66 \%)$ was recorded with $\mathrm{T}_{6}$ 600:200:800g NPK+50g PSB + $40 \mathrm{~g}$ Azotobacter per plant followed by $\mathrm{T}_{7}$ 400:0:400g NPK + 10kg Vermicompost + 50g PSB per plant, T9200:0:400g NPK + 10 $\mathrm{kg}$ Vermicompost+ 50g PSB + 40g Azotobacter per plant and $\mathrm{T}_{8} 200: 0: 400 \mathrm{~g}$ NPK $+10 \mathrm{~kg} \mathrm{FYM}+50 \mathrm{~g}$ PSB+40g Azotobacter per plant and minimum Ascorbic acid (mg/100g of flesh pulp) (436.72) was found in $T_{0}$ Control. The maximum Ascorbic acid (mg/100g of flesh pulp) in $\mathrm{T}_{6}$ may be due to the fact that there was more supplement of nutrients to the plants similar findings were reported by Pankaj and Raj (2008) in Guava and Maity et al., (2006) in Guava \&(A. O.A.C., 1980).
The maximum Total sugar (5.39) was recorded with $\mathrm{T}_{6}$ 600:200:800g NPK+50g PSB + $40 \mathrm{~g}$ Azotobacter per plant followed by $\mathrm{T}_{4}$ 600:400:800 g NPK + 400 g Azotobacter per plant, $\mathrm{T}_{5}$ 600:200:800g NPK + 50g PSB + $40 \mathrm{~g}$ Azotobacter per plant and $\mathrm{T}_{7}$ 400:0:400g NPK +10kg Vermicompost + 50g PSB per plant and minimum Total sugar (4.29) was found in $\mathrm{T}_{0}$ Control. The maximum Total sugar in $\mathrm{T}_{6}$ may be due to the fact that there was more supplement of nutrients to the plants similiar findings were reported by Ranjan (2006) in mosambi and Ram et all., in(mango).

The maximum Juice (\%) (68.76) was recorded with $\mathrm{T}_{6}$ 600:200:800g NPK+50g PSB $+40 \mathrm{~g}$ Azotobacter per plant followed by 
$\mathrm{T}_{5} 600: 200: 800 \mathrm{~g} \quad \mathrm{NPK}+50 \mathrm{~g}$ PSB $+40 \mathrm{~g}$ Azotobacter per plant, T9200:0:400g NPK + $10 \quad \mathrm{~kg} \quad$ Vermicompost $+50 \mathrm{~g} \quad \mathrm{PSB}+40 \mathrm{~g}$ Azotobacter per plant, $\mathrm{T}_{8} 200: 0: 400 \mathrm{~g}$ NPK + $10 \mathrm{~kg}$ FYM+50g PSB+40g Azotobacter per plant and $\mathrm{T}_{4} 600: 400: 800 \mathrm{~g}$ NPK $+400 \mathrm{~g}$ Azotobacter per plant and minimum Juice (\%) (42.78) was found in $\mathrm{T}_{0}$ Control. The maximum Juice $(\%)$ in $\mathrm{T}_{6}$ may be due to the fact that there was more supplement of nutrients to the plants similar findings were reported by DINESH MEENA, RAJESH TIWARI* AND O.P. SINGH (2014) in Aonla

In conclusion the results of present experiment for the 20 years old Aonla cv. Chakaiya variety showed that the treatment T6 (600:200:800 g NPK + 50 g PSB + 40 g Azotobacter per plant) has been found most appropriate integrated nutrient dose followed by, $\quad \mathrm{T}_{8} \quad$ (400:0:400g NPK +10kg Vermicompost $+50 \mathrm{~g}$ PSB per plant) , $\mathrm{T}_{7}$ (400:0:400g NPK +10kg FYM + 50g PSB per plant) and $\mathrm{T}_{9}(200: 0: 400 \mathrm{~g} \mathrm{NPK}+10 \mathrm{~kg}$ FYM+50g PSB+40g Azotobacter per plant) under agro-climatic conditions of paryagraj for obtaining maximum vegetative growth and yield for improving the reproductive parameters, physical characteristics and quality of the fruit and also which is economic with a benefits cost ratio of (1: $5.50)$.

\section{References}

Mahendra, Singh, H.K. and Singh, J.K., (2009). Effect of integrated nutrient management on yield and quality of ber (Z. mauritiana Lamk.) cv. Banarasi Karaka. Asian J. Hort. 04: 47-49. (2009).

Singh, R.P., (2000). Standardization of height and time of wedge grafting in mango (Mangifera indica L.) under western U.P. condition. Ph.D. thesis submitted to SVBPUA\&T, Meerut. (2007).

Ram, R.A. and Rajput, M.S., Role of biofertilizers and manures in production of guava (Psidium guajava L.) Allahabad Safeda. Haryana J. Hort. Sci. 29: 193-94.

Singh, J.K., Singh, D.K., Prasad, J. and Singh, H.K., (2009). Studies on integrated nutrient management in flowering behaviour of bael (Aegle marmelos Correa) cv. Narendra Bael-9. National Symposium on Emerging Trends in Plant Science and Herbal Medicines, held at N.D. University of Agric. \& Tech., Kumarganj, Faizabad (U.P.) on March 17th \& 18th, pp. 78-80. 9

Yadav, Rajesh., Baksh, Hari, Singh, H.K. and Yadav, A.L., (2007). Effect of integrated nutrient management on productivity and quality of aonla (Emblica officinalis Gaertn.) cv. Narendra Aonla -7. Plant Arch. 7: 881-83.

Yadav, A.K., Singh, J.K. and Singh, H.K., (2011). Studies on integrated nutrient management in flowering, fruiting, yield and quality of mango (Mangifera indica L.) cv. Amrapali under high density orcharding. Indian J. Hort. 68(4): 453460.

Pathak P.S. and Bhatt R.K. 2001. Revegetation of degraded lands through agroforestry : retrospects and prospects. (The) Botanica, 51: 127-142.

Mandal, K. K., Rajak, A., Debnath, S., Hasan, M. A. (2013) Integrated nutrient management in aonla cv. A-7 in the red lateritic region of West Bengal. Journal of Crop and Weed. 1 pp.121-123 ref.6.

Mahantesh Kamatyanatti, Ashwani Kumar and RPS Dalal (2019) Effect of integrated nutrient management on growth, flowering and yield of subtropical plum cv. Kala Amritsari Journal of Pharmacognosy and Phytochemistry , 8(1): 1904-1908.

Dinesh Meena, Rajesh Tiwari and O.P. Singh (2014) Effect of nutrient spray on growth,fruit yield and quality of aonla. 
Department of Fruit Science, RVSKVV, Campus College of Horticulture, Mandsaur - 458001 (M.P) Annals journal horticulture of Plant and Soil Research 16 (3): 242-245.

Ranjeet Jamra, Jyoti Kanwar, Rajiv Dubey and Ramesh Chandra Chaudhary (2020).
Effect of integrated nutrient management practices on growth, productivity and profitability of aonla International Journal of Chemical Studies 8(1): 143145.

\section{How to cite this article:}

Balram Pusam and Deepansu Masih. 2020. Effect of Integrated Nutrient Management on Flowering, Fruit Yield and Quality of Aonla (Emblica officinalis Gaertn) cv. Chakaiya. Int.J.Curr.Microbiol.App.Sci. 9(11): 482-488. doi: https://doi.org/10.20546/ijcmas.2020.911.059 